UDC 577.15; 573.6

\title{
Inhibition of immobilized acetylcholinesterase by aflatoxin B1 in potentiometric biosensor
}

\author{
K. V. Stepurska ${ }^{1,2,3}$, M. I. Korobko 2 , V. M. Arkhypova ${ }^{1}$, O. O. Soldatkin ${ }^{1,2}$, F. Lagarde ${ }^{3}$, \\ A. P. Soldatkin ${ }^{1,2}$, S. V. Dzyadevych ${ }^{1,2}$ \\ ${ }^{1}$ Institute of Molecular Biology and Genetics, NAS of Ukraine \\ 150, Akademika Zabolotnoho Str., Kyiv, Ukraine, 03680 \\ 2 Institute of High Technologies, \\ Taras Shevchenko National University of Kyiv \\ 2, korp.5, Pr. Akademika Hlushkova, Kyiv, Ukraine, 03022 \\ ${ }^{3}$ University Claude Bernard Lyon 1, Institute of Analytical Sciences, UMR5280 CNRS/UCBL/ENS, \\ 5 rue de la Doua, 69100 Villeurbanne, France. \\ stepurskaya@gmail.com
}

\begin{abstract}
Aim. To identify a type of inhibition of immobilized acetylcholinesterase by aflatoxin B1. Methods. A bioselective element of the potentiometric biosensor was created using acetylcholinesterase, which was covalently immobilized on the surface of the $\mathrm{pH}-\mathrm{FET}$ sensor by glutaraldehyde crosslinking with bovine serum albumin. Results. Optimal conditions for the potentiometric biosensor operation such as $\mathrm{pH}$-optimum of the enzyme action and its inhibition were defined. An apparent Michaelis constant, as well as a maximum initial reaction rate of immobilized acetylcholinesterase as a part of the biosensor were determined. The type of reversible inhibition of immobilized acetylcholinesterase by aflatoxin B1 in potentiometric biosensor was identified by using a new graphical "degree of inhibition" method and the obtained result was confirmed with one of the tradi-tional methods, such as the Lineweaver-Burk plot. Conclusions. This study helps to understand the mechanisms of enzyme inhibition in biosensors and brings the biosensor implementation closer.
\end{abstract}

Keyword s: biosensor, immobilized acetylcholinesterase, type of inhibition, aflatoxin B1, potentiometric transducer.

\section{Introduction}

Aflatoxins, the secondary metabolites of molds, are the life-threatening mycotoxins. An acute toxic effect of aflatoxins is associated with the fact that they are one of the most powerful hepatotropic poisons. Even a low level of these toxins in the diet may be detrimental for the human health. Aflatoxins are produced by some strains of microscopic fungi of the genus Aspergillus. They are able to grow and form toxins on various natural substrates such as raw materials for food products, fodder and other foodstuffs.
Under natural conditions, aflatoxins in large amounts occur most commonly in peanuts and corn; they can also accumulate in various nuts, oilseeds, wheat, barley, cocoa and coffee beans. Notably, aflatoxins practically are not destroyed in the course of ordinary cooking and food processing (the destruction point of aflatoxins is $268-269^{\circ} \mathrm{C}$ ). Currently, the aflatoxin family is represented by four natural aflatoxins B1, B2, G1, G2 and more than 10 compounds, which are the metabolites or derivatives of the main group (M1, M2, V2A, G2a, GM1, P1, Q1, etc.) $[1]$. 
The members of the blue (B) fluorescent group (aflatoxins B1 and B2) are characterized by the fusion of a cyclopentenone ring with a lactone ring of the coumarin moiety, whereas the green $(G)$ fluorescent toxins (aflatoxins G1 and G2) contain a fusedring lactone [1]. The capability of fluorescence determined almost all physical and chemical methods of quantitative and qualitative detection of aflatoxins, which include TLC [2], HPLC [3] and different combinations of liquid chromatography with mass spectrometry [4].

An alternative method of determining aflatoxin is an inhibitory analysis using the enzyme biosensors based on acetylcholinesterase (AChE) [5-8]. The biosensor functioning is based on the following enzymatic reaction:

\section{AChE \\ Acetylcholine $+2 \mathrm{H}_{2} \mathrm{O} \rightarrow$ Choline $+\mathrm{CH}_{3} \mathrm{COO}^{-}+\mathrm{H}^{+}$}

In the course of enzymatic reaction (1), acetylcholinesterase decomposes acetylcholine to choline and acetic acid. Acetic acid dissociates, thus increasing the local concentration of protons in the working membrane. This, in turn, leads to changes in the solution $\mathrm{pH}$ close to the transducer surface, which is registered by a potentiometric transducer. Aflatoxins can inhibit the acetylcholinesterase activity and it is the basis for the development of AChE-biosensors for the aflatoxin determination.

The inhibitors may be reversible or irreversible. The reversible inhibitors weakly interact with their target enzyme and are easily removed, whereas the irreversible inhibitors form strong stable interactions and can be removed only chemically (if can be removed at all). The reversible inhibition reaches equilibrium depending on the inhibition constant, which characterizes the enzyme affinity for the inhibitor. The irreversible inhibition reaches maximum when the enzyme is completely bound with the inhibitor. The reversible inhibitors are further classified into competitive, noncompetitive, uncompetitive and mixed types according to the mechanism of their action.
There are various graphical methods of determining a type of inhibition, including methods of Lineweaver-Burk [9], Dixon [10], Cornish-Bowden [11], Eadie-Hofstee [12], etc. When using the biosensors based on the inhibition analysis, the socalled "degree of inhibition" method is applied [13].

The present work is devoted to a detailed study on biochemical properties of the inhibition of immobilized acetylcholinesterase by aflatoxin B1 within the potentiometric biosensor. To ascertain a type of inhibition is important for a better understanding of the mechanism of enzyme inhibition in biosensor [14]. The updating of some inhibitory characteristics will also allow the optimization of the AChE-based biosensors for aflatoxin determination.

\section{Materials and Methods}

\section{Materials}

Acetylcholinesterase (AChE) from electric eel (EC 3.1.1.7), the activity of $426 \mathrm{U} / \mathrm{mg}$, was immobilized on the surface of potentiometric transducer by the method of covalent crosslinking of enzyme in the vapour of $50 \%$ aqueous solution of glutaraldehyde (GA) ("Sigma-Aldrich Chemie", Germany). Bovine serum albumin (BSA, fraction $\mathrm{V}$ ) and glycerol of domestic production were used as additional substances for the enzyme immobilisation.

Acetylcholine chloride $(\mathrm{AChCl})$ was used as a substrate, and aflatoxin B1 (AFB1) - as an inhibitor, both were from "Sigma-Aldrich Chemie" (Germany).

The optimization of $\mathrm{pH}$ of immobilized acetylcholinesterase was performed in $2.5 \mathrm{mM}$ multicomponent buffer ("polymix" buffer) $[15,16]$. The compounds for the buffer "Polimix" preparation (purity 98.5-99 \%, Helicon, Russia) were the next: $2.5 \mathrm{mM}$ Na-tetraborate $\left(\mathrm{Na}_{2} \mathrm{~B}_{4} \mathrm{O}_{7}\right)$ (anhydrous) ( $\left.\mathrm{pH} 7.8-9,2\right)$, $2.5 \mathrm{mM}$ tris ( $\mathrm{pH} 7.0-9.2), 2.5 \mathrm{mM}$ potassium phosphate (pH 6-8), citric acid (2.5 mM) and sodium chloride (150 mM).

Phosphate buffer solutions were prepared from $\mathrm{KH}_{2} \mathrm{PO}_{4}$ salt (purity $98.5 \%$, Helicon, Russia) and $\mathrm{NaOH}$ (purity $99 \%$, Helicon, Russia). 


\section{Potentiometric transducers}

In the work, we used the portable measuring device and sensor chips fabricated at the V.Ye. Lashkaryov Institute of Semiconductor Physics (Kiev, Ukraine). The sensor chips contain the differential pair of $\mathrm{p}$ channel transistors on the monocrystalline silicon substrate of total area $8 \times 8 \mathrm{~mm}^{2}$. The sensor elements demonstrated the intrinsic $\mathrm{pH}$-sensitivity of approximately $40 \mathrm{mV} / \mathrm{pH}$ and transconductance of 400 $500 \mu \mathrm{A} / \mathrm{V}$, thus providing $\mathrm{pH}$-sensitivity of the transistor channel current of $15-20 \mu \mathrm{A} / \mathrm{pH}$. The response of pH-FET sensor was measured by means of the current-to-voltage converter circuit with the sensors working in the current source mode with active load. The threshold voltage of the used $\mathrm{pH}-\mathrm{FET}$ s was about $-2.5 \mathrm{~V}$. The measurements were performed with the initial channel current magnitude of approximately $500 \mu \mathrm{A}$, drain-to-source voltage of approximately 2 $\mathrm{V}$, transistor bulk connected to the source [17].

\section{Preparation and immobilization of bioselective elements}

To prepare working enzyme membranes the following solution was used: $1 \%$ acetylcholinesterase, $4 \%$ BSA and $10 \%$ glycerol in $20 \mathrm{mM}$ phosphate buffer,

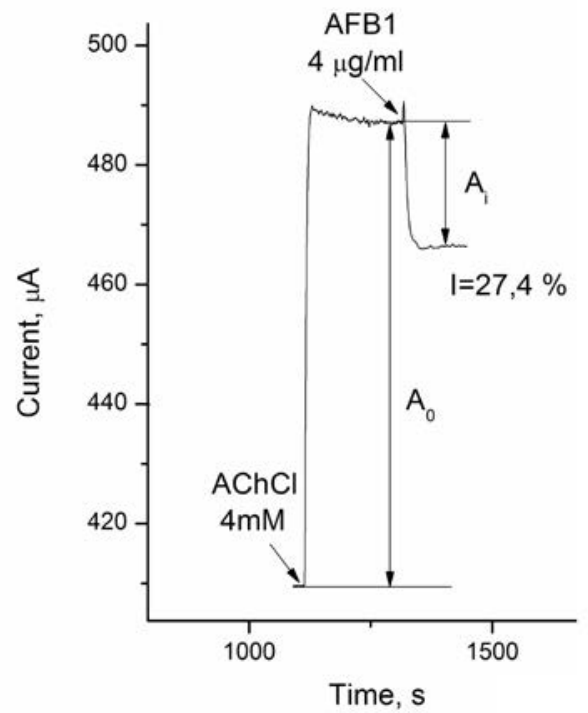

Fig. 1. Real response to $4 \mathrm{mM} \mathrm{AChCl}$ before and after inhibition by $4 \mu \mathrm{g} / \mathrm{ml}$ of AFB1. Measurements were performed in $5 \mathrm{mM}$ phosphate buffer, $\mathrm{pH} 6.5$ at room temperature.
$\mathrm{pH}$ 7. The mixture for reference membrane was prepared in the same way, but no enzyme was used, only BSA and glycerol of final concentrations $5 \%$ and $10 \%$ correspondingly were solved in $20 \mathrm{mM}$ phosphate buffer, $\mathrm{pH}$ 7. After deposition of the prepared mixture on the working surface of potentiometric transducers, the latter were placed in saturated glutaraldehyde vapour for $20 \mathrm{~min}$ and then kept for $5 \mathrm{~min}$ in air at room temperature. Prior to the operation, the membranes were washed with buffer solution to remove the excess of unbound components.

\section{Procedure of measurements}

The measurements were carried out at room temperature in $5 \mathrm{mM}$ phosphate buffer, $\mathrm{pH} 6.5$, or in $2.5 \mathrm{mM}$ "polymix" buffer of different $\mathrm{pH}$, in an open cell with constant stirring. The substrate and inhibitor concentrations in the working cell were achieved by addition of aliquots of the corresponding stock solutions (Fig. 1).

The level of enzyme inhibition (I \%) was evaluated by comparing the biosensor responses to the substrate concentration before $\left(\mathrm{A}_{0}\right)$ and after $\left(\mathrm{A}_{\mathrm{i}}\right)$ inhibition according to the formula:

$$
I \%=\left(\frac{A_{0}-A_{i}}{A_{0}}\right) \times 100 \%
$$

\section{Results and Discussion}

$\mathrm{pH}$ of the working buffer is a key parameter that is expected to affect the biosensor performance, since it is known to have a major impact on the enzyme stability and activity. In this study, $2.5 \mathrm{mM}$ «polymix» working buffer was used to regulate $\mathrm{pH}$ value in the 4.5 to 9.5 range. Buffer concentration of $2.5 \mathrm{mM}$ was chosen as it allowed getting sufficient biosensor response whereas at higher concentrations the signal decreased significantly. The biosensor response to $4 \mathrm{mM} \mathrm{AChCl}$ and the level of inhibition by $2 \mu \mathrm{g} / \mathrm{ml}$ AFB1 were measured changing $\mathrm{pH}$ by 0.5 unit at each measurement. The results are depicted in Fig. 2.

As can be seen, the optimal $\mathrm{pH}$ values for biosensor response operation were observed in the 6.5-8.5 


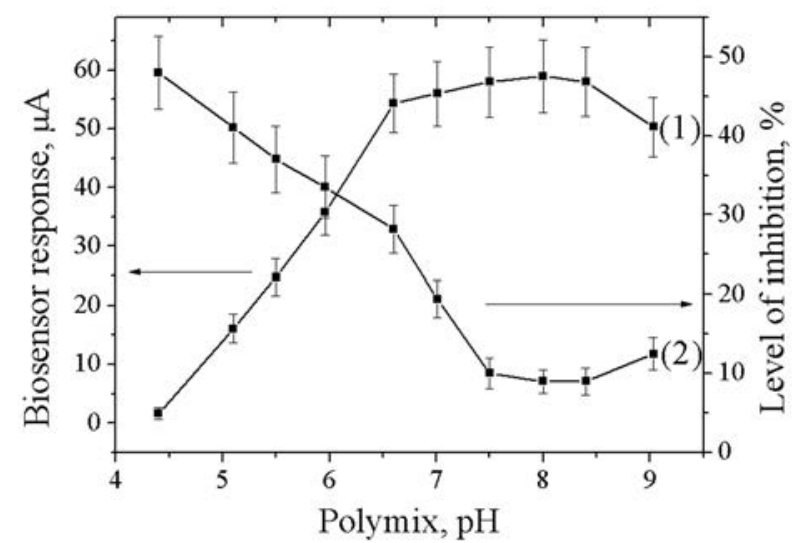

Fig. 2. Influence of $\mathrm{pH}$ on the AChE-based biosensor response (1) and inhibition level in the presence of $2 \mu \mathrm{g} / \mathrm{ml}$ aflatoxin B1 (2). Measurements were performed in $2.5 \mathrm{mM}$ "polymix" buffer at room temperature.

range whereas the highest levels of inhibition were detected between $\mathrm{pH} 4.5$ and 6.5. The best compromise was therefore achieved at $\mathrm{pH} 6.5$.

Analyzing the type of inhibition of immobilized AChE by aflatoxin, the conclusion can be made about the nature of interaction. After inhibition, the biosensor response and, thus, the biomembrane activity can be completely restored by ordinary washing with the working buffer, which indicates weak aflatoxin-enzyme interaction, i.e. aflatoxin is a reversible inhibitor.

A graphical method that allows the determination of the type of reversible inhibition has been recently reported in the literature [13]. In this method, a number of calibration curves are plotted, demonstrating the dependence of the degree of the immobilized enzyme inhibition in biosensor on different concentrations of the inhibitor. Each curve is plotted at a fixed value of substrate concentration, for instance, the substrate concentration equal to the $K_{m}$ value or the saturating concentration. For each curve, the degree of inhibition $I_{50}$ is determined. It is numerically identical to the inhibitor concentration, at which the degree of immobilized enzyme inhibition in biosensor is $50 \%$. Next, an analysis of the changes in the calibration curve and the inhibition degree $I_{50}$ allows the conclusion regarding the type of inhibition. If $I_{50}$ increases with increasing the substrate concentration, and the calibration curve shifts to the higher concentration range, it means that the inhibition is of competitive type. If $I_{50}$ decreases with increasing substrate concentration and the calibration curve shifts to the lower concentration range, it corresponds to the uncompetitive type of inhibition. In the case of the noncompetitive type of inhibition, $I_{50}$ and calibration curve do not change. Finally, in the case of inhibition of mixed type, $I_{50}$ increases with increasing substrate concentration likely to the competitive type of inhibition, but the calibration curve shift is significantly lower. For example, a 10-fold increase in the substrate concentration causes an increase of $I_{50}$ for the competitive type by 5.5 times whereas for the mixed type - by only 1.5 times.

Prior to the determination of the type of reversible inhibition, it was necessary to evaluate the apparent Michaelis constant $K_{m}^{a p p}$ for immobilized AChE. Basically, the Michaelis constant for native enzymes is determined as half the maximum initial rate. With regard to the immobilized enzymes as the biosensor constituents, the estimation of this rate is almost impossible. It should be taken into account that it is inconsistent to equate the speed of biosensor response with the rate of biochemical reaction in the membrane, as the former is defined by certain electrochemical peculiarities of the registration method

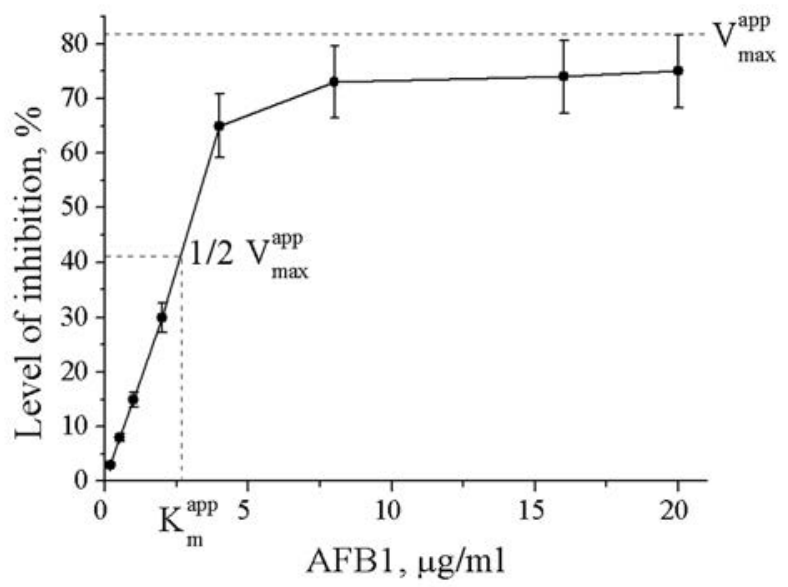

Fig. 3. Dependence of AChE-biosensor response on acetylcholine concentration. Measurements were performed in $5 \mathrm{mM}$ phosphate buffer, $\mathrm{pH} 6.5$, at room temperature. 
and diffusion properties. Considering the fact that the time of responses of the biosensor at all substrate concentrations is almost the same, we assume that it would be appropriate to apply directly the value of biosensor response for plotting the graphs as it is proportional to the initial rate of the enzymatic reaction with use of immobilized enzyme. Therefore, to determine the Michaelis constant for the enzyme immobilized on the surface of the potentiometric transducer, the curves of dependence of the biosensor response on the $\mathrm{AChCl}$ concentration were plotted. The data obtained are presented in both direct (Fig. 3) and inverse (Fig. 4) coordinates.

The graph (Fig. 5) shows that the maximum biosensor response is $77 \mu \mathrm{A}$, i.e. the maximum initial rate $V_{\max }$ is proportional to this value. Determining the apparent Michaelis constant as half the maximum rate, we obtain $K_{m}^{a p p}=2.5 \mathrm{mM}$. Another method of the Michaelis constant determination suggests the presentation of the same data in inverted Lineweaver-Burk coordinates (Fig. 6). The obtained straight line cuts off on the $\mathrm{X}$ - and Y-axes the reciprocal values $K_{m}$ and $V_{\max }$, respectively. The equation of the straight line obtained (Fig. 6) is: $y=0.0334 \mathrm{x}$

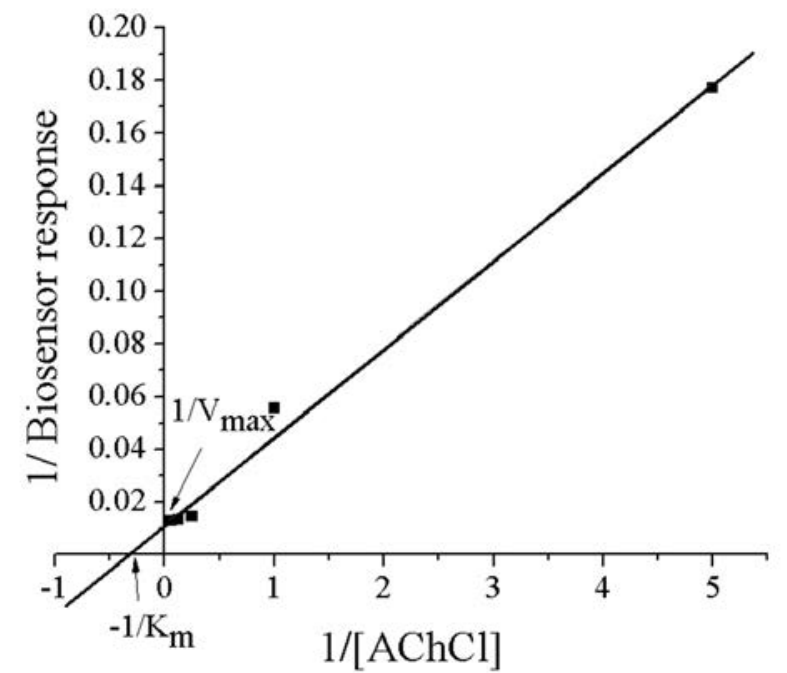

Fig. 4. Dependence of the AChE-biosensor response on acetylcholine concentration in inverted Lineweaver-Burk coordinates. Measurements were performed in $5 \mathrm{mM}$ phosphate buffer, $\mathrm{pH}$ 6.5 , at room temperature.
+0.0116 . From this equation, the reciprocal value $1 / K_{m}^{a p p}=0.3475$. The apparent Michaelis constant determined by this method is $K_{m}^{a p p}=2.8 \mathrm{mM}$.

Thus, the obtained apparent Michaelis constant of acetylcholinesterase immobilized on the surface of the potentiometric transducer was $2.3 \mathrm{mM}$ or $2.8 \mathrm{mM}$, depending on the method of determination. For convenience, $K_{m}^{a p p}=2.5 \mathrm{mM}$ was used further on.

For the next experiment on determining the type of inhibition of immobilized AChE by the "degree of inhibition" method, the substrate concentrations of $2.5 \mathrm{mM}$ and $20 \mathrm{mM}$ were fixed. They corresponded respectively to the apparent Michaelis constant $K_{m}^{a p p}$ and $8 K_{m}^{a p p}$, which is saturating concentration. The calibration curves for aflatoxin B1 determination (dependence of degree of inhibition on the inhibitor concentration) were plotted for two fixed substrate concentrations (Fig. 5).

As seen, with an increase of the substrate concentration, $I_{50}$ also increases. Graphically, this corresponds to a rightward shift of the calibration curve. Since the shift is slight and the ratio of $I_{50}$ at substrate concentration $8 K_{m}^{a p p}\left(I_{50}=21 \mu \mathrm{g} / \mathrm{ml}\right)$ to $I_{50}$ at substrate concentration $K_{m}^{a p p}\left(I_{50}=10.5 \mu \mathrm{g} / \mathrm{ml}\right)$ is 2 ,

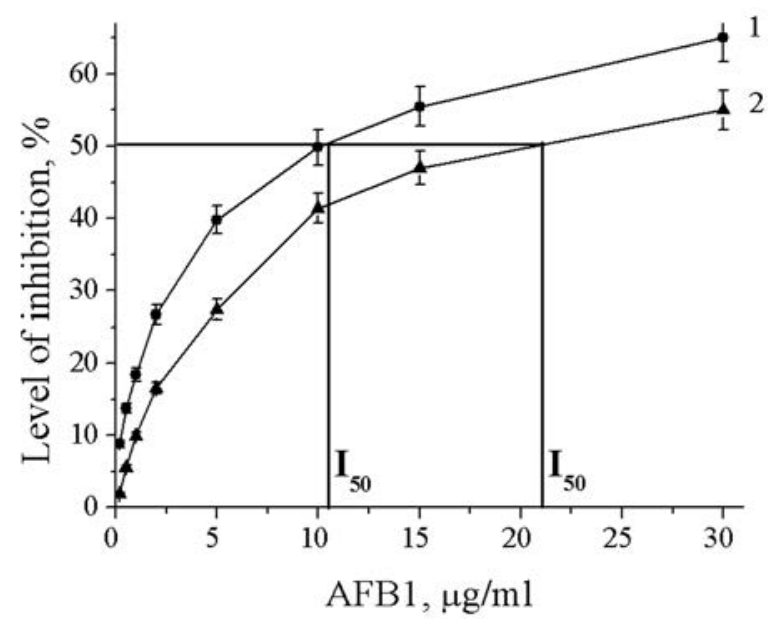

Fig. 5. Dependence of level of inhibition of immobilized AChE on aflatoxin B1 concentration in the presence of $2.5 \mathrm{mM}$ (1) and $20 \mathrm{mM}$ (2) $\mathrm{AChCl}$. Measurements were performed in $5 \mathrm{mM}$ phosphate buffer, $\mathrm{pH} 6.5$, at room temperature. 
the conclusion can be made that the inhibition is of the mixed type.

It was interesting to confirm the obtained results using one of the traditional methods of identifying the type of inhibition, such as the Lineweaver-Burk, Dixon, Cornish-Bowden, Eadie-Hofstee methods. They are based on the construction of the MichaelisMenten equation in different coordinate systems: $1 / \mathrm{V}$ versus $1 /[\mathrm{S}]$, v versus $\mathrm{V} /[\mathrm{S}], 1 / \mathrm{V}$ versus $[\mathrm{I}]$ and $[\mathrm{S}] / \mathrm{V}$ ([I]) respectively, where $\mathrm{V}$ - an initial rate of the enzymatic reaction, $[\mathrm{S}],[\mathrm{I}]$ - concentrations of substrate and inhibitor respectively. We chose the Lineweaver-Burk method as the most commonly used. To invert the Michaelis-Menten equation into the Lineweaver-Burk plot it is necessary to determine the initial rates of the enzymatic reaction at different substrate concentrations in the presence of inhibitor and without it and to plot the $1 / \mathrm{V}$ vs $1 /[\mathrm{S}]$ graphs. The type of inhibition can then be identified by the analysis of these lines. For competitive inhibition, the lines intersection should be on the Y-axis $(1 / \mathrm{V})$, meaning that the maximum rate does not change, and the apparent Michaelis constant increases. For noncompetitive inhibition, the lines intersection should be on the $\mathrm{X}$-axis $(1 /[\mathrm{S}])$, showing that in this case, in contrast,

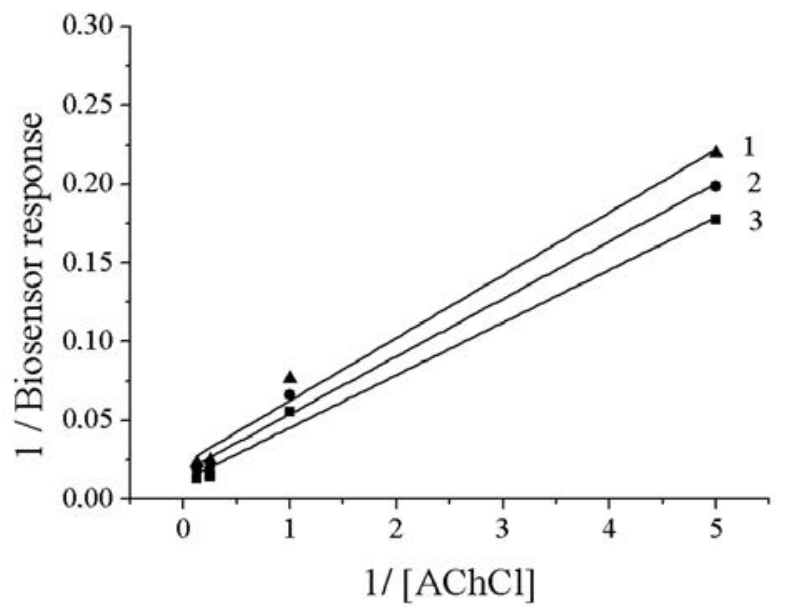

Fig. 6. Dependence of AChE-biosensor response on acetylcholine concentration in the presence of $10 \mu \mathrm{g} / \mathrm{ml}(1)$ and $5 \mu \mathrm{g} / \mathrm{ml}$ (2) of aflatoxin B1 and without inhibitor (3) in inverse Lineweaver-Burk coordinates. Measurements were performed in $5 \mathrm{mM}$ phosphate buffer, $\mathrm{pH}$ 6.5, at room temperature. the apparent Michaelis constant remains unchanged, and the maximum rate decreases. For uncompetitive inhibition, both the maximum rate and apparent Michaelis constant decrease by the same times, graphically it looks like parallel straight lines. And finally, for mixed inhibition, the maximum speed decreases and the apparent Michaelis constant can either increase or decrease, therefore graphically the lines intersection should be not on $\mathrm{X}$ - and Y-axes.

During the experiment, the changes in the biosensor response to different substrate concentrations were investigated with no inhibitor as well as in the presence of various aflatoxin B1 concentrations (5 $\mu \mathrm{g} / \mathrm{ml}$ and $10 \mu \mathrm{g} / \mathrm{ml}$ ). The experimental results were presented in the double-inverted LineweaverBurk coordinates (Fig. 6).

From the equations of the regression lines (Fig. 6), the apparent Michaelis constants of immobilized AChE can be calculated in the absence of inhibitor $\left(K_{m}^{a p p}=2.8\right)$ and in the presence of $5 \mu \mathrm{g} / \mathrm{ml}$ inhibitor AFB1 $\left(K_{m}^{a p p}=2.1\right)$ and $10 \mu \mathrm{g} / \mathrm{ml} \mathrm{AFB1}\left(K_{m}^{a p p}=1.8\right)$. The fact that the lines do not intersect on any of the axes and that at the increasing inhibitor concentration the values of both $K_{m}^{a p p}$ and maximum biosensor response (proportional to $V_{\max }$ ) decrease, indicates that aflatoxin $\mathrm{B} 1$ is a reversible acetylcholinesterase inhibitor of mixed type.

\section{Conclusion}

The detailed study of the mechanism of immobilized acetylcholinesterase inhibition by aflatoxin B1 within the potentiometric biosensor was presented in the work. The optimum $\mathrm{pH}$ of immobilized acetylcholinesterase was determined to be $6.5-8.5$ for the substrate decomposition and 4.5-6.5 - for inhibition by aflatoxin B1. Using two methods, the "degree of inhibition" method and the Lineweaver-Burk plot, we analyzed the inhibitory effect of aflatoxin B1 on acetylcholinesterase, immobilized on the potentiometric transducer surface. Both methods showed that immobilized acetylcholinesterase inhibition by aflatoxin B1 is of mixed type. An increase in the substrate concentration was shown to result in increasing $I_{50}$; its value was $10.5 \mu \mathrm{g} / \mathrm{ml}$ at the substrate con- 
centration equal $K_{m}^{a p p}$, and $21 \mu \mathrm{g} / \mathrm{ml}$ at the saturating concentration $8 K_{m}^{a p p}$. It was also found that at increasing aflatoxin B1 concentration, the Michaelis constant and biosensor response reduced.

\section{Acknowledgements}

The authors gratefully acknowledge the financial support of this study by the National Academy of Sciences of Ukraine in the frame of complex scientific-technical program "Sensor devices for medicalecological and industrial purposes: metrology and trial performance".

\section{REFERENCES}

1. Kensler TW, Roebuck BD, Wogan GN, Groopman JD. Aflatoxin: a 50-year odyssey of mechanistic and translational toxicology. Toxicol Sci. 2011;120 Suppl 1:S28-48.

2. Var I, Kabak B, Gök F. Survey of aflatoxin B1 in helva, a traditional Turkish food, by TLC. Food Control. 2007;18(1): 59-62.

3. Khayoon WS, Saad B, Yan CB, Hashim NH, Ali ASM, Salleh MI, Salleh $B$. Determination of aflatoxins in animal feeds by HPLC with multifunctional column clean-up. Food Chem. 2010; 118(3):882-6.

4. Solfrizzo M, De Girolamo A, Lattanzio VMT, Visconti A, Stroka J, Alldrick A, van Egmond HP. Results of a proficiency test for multi-mycotoxin determination in maize by using methods based on LC-MS/(MS). Qual Assur Saf Crop Foods. 2013;5(1):15-48.

5. Pohanka M. Spectrophotomeric assay of aflatoxin B1 using acetylcholinesterase immobilized on standard microplates. Anal Lett. 2013;46(8):1306-15.

6. Puiu M, Istrate $O$, Rotariu L, Bala C. Kinetic approach of aflatoxin B1-acetylcholinesterase interaction: a tool for developing surface plasmon resonance biosensors. Anal Biochem. 2012;421(2):587-94.

7. Soldatkin OO, Burdak OS, Sergeyeva TA, Arkhypova VM, Dzyadevych SV, Soldatkin AP. Acetylcholinesterase-based conductometric biosensor for determination of aflatoxin B1. Sens Actuators B Chem. 2013; 188:999-1003.

8. Stepurska KV, Soldatkin OO, Arkhypova VM, Soldatkin AP, Lagarde F, Jaffrezic-Renault N, Dzyadevych SV. Development of novel enzyme potentiometric biosensor based on $\mathrm{pH}$-sensitive field-effect transistors for aflatoxin B1 analysis in real samples. Talanta. 2015;144:1079-84.

9. Lineweaver $H$, Burk $D$. The determination of enzyme dissociation constants. J Am Chem Soc. 1934; 56(3):658-66.

10. Butterworth PJ. The use of Dixon plots to study enzyme inhibition. Biochim Biophys Acta. 1972;289(2):251-3.
11. Cornish-Bowden A. A simple graphical method for determining the inhibition constants of mixed, uncompetitive and non-competitive inhibitors. Biochem J. 1974;137(1): 143-4.

12. Atkins GL, Nimmo IA. A comparison of seven methods for fitting the Michaelis-Menten equation. Biochem J. 1975; 149(3):775-7.

13. Amine A, El Harrad L, Arduini F, Moscone D, Palleschi G. Analytical aspects of enzyme reversible inhibition. Talanta. 2014;118:368-74.

14. Benilova IV, Arkhypova VN, Dzyadevych SV, Jaffrezic-Renault $N$, Martelet $C$, Soldatkin AP. Kinetics of human and horse sera cholinesterases inhibition with solanaceous glycoalkaloids: study by potentiometric biosensor. Pestic Biochem Physiol. 2006; 86(3):203-10.

15. Arkhypova VN, Dzyadevych SV, Soldatkin AP, El'skaya AV, Martelet $C$, Jaffrezic-Renault $N$. Development and optimisation of biosensors based on $\mathrm{pH}$-sensitive field effect transistors and cholinesterases for sensitive detection of solanaceous glycoalkaloids. Biosens Bioelectron. 2003;18(8): 1047-53.

16. Dzyadevych SV, Arkhypova VN, Soldatkin AP, El'skaya AV, Martelet C, Jaffrezic-Renault $N$. Enzyme biosensor for tomatine detection in tomatoes. Anal Lett. 2004;37(8):1611-24.

17. Dzyadevych SV, Soldatkin AP, El'skaya AV, Martelet C, Jaffrezic-Renault $N$. Enzyme biosensors based on ion-selective field-effect transistors. Anal Chim Acta. 2006;568(1-2): 248-58.

\section{Вивчення інгібування іммобілізованої ацетилхолінестерази афлатоксином В1 в складі потенціометричного біосенсора}

К. В. Степурська, М. І. Коробко, В. М. Архипова, О. О. Солдаткін, Ф. Лагард, О. П. Солдаткін, С. В. Дзядевич

Мета. Визначення типу інгібування іммобілізованої ацетилхолінестерази афлатоксином В1. Методи. Біоселективний елемент потенціометрического біосенсора був створений використовуючи поперечну зшивку ацетилхолінестерази з бичачим сироватковим альбуміном в мембрані за допомогою глутарового альдегіду. Результати. Визначено оптимальні умови роботи потенціометричного біосенсора, такі як $\mathrm{pH}$ оптимум роботи ферменту та його інгібування. Були визначені уявна константа Міхаеліса, а також максимальна початкова швидкість ферментативної реакції іммобілізованої ацетилхолінестерази в складі біосенсора. Тип оборотного інгібування іммобілізованої ацетилхолінестерази афлатоксином В1 в складі потенціометричного біосенсора був ідентифікований 3 використанням нового графічного методу - методу «ступеня інгібування», отриманий результат був підтверджений за допомогою одного із традиційних методів -ЛайнуівераБерка. Висновки. Це дослідження допомагає зрозуміти меха- 
нізми інгібування ферменту в складі біосенсора та наближує впровадження біосенсора у виробництво.

Кл юч о в і сл о в а: біосенсор, іммобілізована ацетилхолінестераза, тип інгібування, афлатоксин В1, потенціометричний перетворювач.

\section{Изучение ингибирования иммобилизованной ацетилхолинестеразы афлатоксином В1 в составе потенциометрического биосенсора}

Е. В. Степурская, М. И. Коробко, В. Н. Архипова, А. А. Солдаткин, Ф. Лагард, А. П. Солдаткин, С. В. Дзядевич

Цель. Определение типа ингибирования иммобилизованной ацетилхолинэстеразы афлатоксином В1. Методы. Биоселективный элемент потенциометрического биосенсора был создан, используя поперечную сшивку ацетилхолинэстеразы с бычьим сывороточным альбумином в мембране при помощи глутарового альдегида. Результаты. Определены оптималь- ные условия работы потенциометрического биосенсора, такие как рН-оптимум работы фермента и его ингибирования. Были определены кажущаяся константа Михаэлиса, а также максимальная начальная скорость ферментативной реакции иммобилизованной ацетилхолинэстеразы в составе биосенсора. Тип обратимого ингибирования иммобилизованной ацетилхолинестеразы афлатоксином В1 в составе потенциометрического биосенсора был установлен при помощи нового графического метода - метода «степени ингибирования», полученный результат был подтвержден с помощью одного из традиционных методов - Лайнуивера-Берка. Выводы. Это исследование помогает понять механизмы ингибирования фермента в составе биосенсора и приближает внедрение биосенсора в производство.

Кл юч е в ы е с л о в а: биосенсор, иммобилизованная ацетилхолинестераза, тип ингибирования, афлатоксин В1, потенциометрический преобразователь.

Received 20.05.2016 